\title{
LIMNOLOGICAL AND ECOTOXICOLOGICAL STUDIES IN THE CASCADE OF RESERVOIRS IN THE TIETÊ RIVER (SÃO PAULO, BRAZIL)
}

\author{
RODGHER, S. ${ }^{1}$, ESPÍNDOLA, E. L. G. ${ }^{1}$, ROCHA, O. ${ }^{2}$, FRACÁCIO, R. ${ }^{3}$, \\ PEREIRA, R. H. G. ${ }^{1}$ and RODRIGUES, M. H. S. ${ }^{1}$ \\ ${ }^{1}$ Center of Water Resources and Applied Ecology, São Carlos School of Engineering, University of São Paulo, USP, \\ Av. Trabalhador São Carlense, 400, C.P. 292, CEP 13560-970, São Carlos, SP, Brazil \\ ${ }^{2}$ Dept. of Ecology and Evolutionary Biology, Federal University of São Carlos, Rodovia Washington Luiz, km 235, \\ C.P. 676, CEP 13565-905, São Carlos, SP, Brazil \\ ${ }^{3}$ Dept. of Hydrobiology, Federal University of São Carlos, Rodovia Washington Luiz, km 235, \\ C.P. 676, CEP 13565-905, São Carlos, SP, Brazil \\ Correspondence to: Suzelei Rodgher, Center of Water Resources and Applied Ecology, \\ São Carlos School of Engineering, University of São Paulo, USP, \\ Av. Trabalhador São Carlense, 400, C.P. 292, CEP 13560-970, \\ São Carlos, SP, Brazil, e-mail: surodgher@uol.com.br
}

Received January 8, 2004 - Accepted May 10, 2004 - Distributed November 30, 2005

(With 4 figures)

\begin{abstract}
An evaluation was made of the quality of samples of water and sediment collected from a series of reservoirs in the Tietê River (SP), based on limnological and ecotoxicological analyses. The samples were collected during two periods (Feb and Jul 2000) from 15 sampling stations. Acute toxicity bioassays were performed using the test organism Daphnia similis, while chronic bioassays were carried out with Ceriodaphnia dubia and Danio rerio larvae. The water samples were analyzed for total nutrients, total suspended matter and total cadmium, chromium, copper and zinc concentrations, while the sediment samples were examined for organic matter, granulometry and potentially bioavailable metals (cadmium, chromium, copper and zinc). The results obtained for the limnological variable, revealed differences in the water quality, with high contribution of nutrients and metals for Tietê and Piracicaba rivers, besides the incorporation and sedimentation, consequently causing a reduction of materials in Barra Bonita reservoir, thus promoting the improvement of the water quality in the other reservoirs. The toxicity bioassays revealed acute toxicity for Daphnia similis only in the reservoirs located below Barra Bonita dam. On the other hand, chronic toxicity for Ceriodaphnia dubia and acute for Danio rerio showed a different pattern, decreasing in magnitude from Barra Bonita to Três Irmãos, demonstrating an environmental degradation gradient in the reservoirs.
\end{abstract}

Keywords: reservoirs ecology, limnology, ecotoxicology, Tietê River.

\section{RESUMO}

\section{Estudos limnológicos e ecotoxicológicos na cascata de reservatórios do rio Tietê (São Paulo, Brasil)}

O presente trabalho visou avaliar a qualidade de amostras de água e sedimento dos reservatórios em cascata do rio Tietê (SP) através de análises limnológicas e ecotoxicológicas. Foram realizadas coletas de água e sedimento em dois períodos (fevereiro e julho de 2000) e em 15 estações de amostragem. Foram realizados bioensaios de toxicidade aguda para Daphnia similis, de toxicidade crônica para Ceriodaphnia dubia e para larvas pós-eclodidas de Danio rerio. Análises de nutrientes totais, material em suspensão total e cádmio, cromo, cobre e zinco foram realizadas para as amostras de água e análises de matéria orgânica, granulometria e metais biodisponíveis (cádmio, cromo, cobre e zinco) para o sedimento. Os resultados obtidos para as variáveis limnológicas, revelaram diferenças na qualidade da água, com elevado aporte 
de nutrientes e metais pelos rios Tietê e Piracicaba, além da incorporação, da sedimentação e da redução de materiais no reservatório de Barra Bonita, promovendo a melhoria da qualidade da água nos demais reservatórios. Os bioensaios revelaram toxicidade aguda para Daphnia similis somente nos reservatórios localizados à jusante da barragem de Barra Bonita, porém os bioensaios de toxicidade crônica com Ceriodaphnia dubia e com Danio rerio revelaram toxicidade decrescendo em magnitude de Barra Bonita à Três Irmãos, evidenciando um gradiente de degradação ambiental nos reservatórios.

Palavras-chave: ecologia de reservatórios, limnologia, ecotoxicologia, Rio Tietê.

\section{INTRODUCTION}

The construction of reservoirs for a variety of purposes represents one of the greatest human experiences in the modification of the natural ecosystems. Making use of rivers by building a series of reservoirs is a common practice in large Brazilian rivers. In the state of São Paulo (southeastern Brazil) this system is commonly adopted for maximum exploitation of hydroelectric energy potential. Numerous consecutive dams create a group of reservoirs that receive and accumulate organic and inorganic matter from adjacent systems. Exemplifying this kind of system, along its length, the Tietê River comprises the reservoirs of Barra Bonita, Álvaro de Souza Lima (Bariri), Ibitinga, Mário Lopes Leão (Promissão), Nova Avanhandava and Três Irmãos.

These six reservoirs were built between the 1960's and 90's. The first of the series was concluded in 1964 (Barra Bonita reservoir) and the last one in 1991 (Três Irmãos reservoir). They were built in response to the growing demand for electric energy in southeastern Brazil, as well as for urban, industrial and agricultural use, including recreation and navigation. According to the National Environmental Council (CONAMA - Resolution 20/1986), which establishes Brazil's water quality standards based on predominant usage, the water in the middle and lower Tietê reservoirs was classified under Category 2 (water suitable for domestic consumption, recreation, irrigation, and protection of aquatic communities).

An important point for consideration in the evaluation of this systemis the reservoirs' cascade-like arrangement, since any modification in the reservoirs upstream affects the ones downstream. Studies developed by Armengol (1977), Margalef (1983), and Straškraba (1994) demonstrated that this physical arrangement should result in increasingly improved water quality, since part of the nutrients and pollutants may be retained in the uppermost portion of the system. Matsumura-Tundisi et al., (1981) observed decreasing eutrophication in the Tietê River's reservoirs from Barra Bonita to Nova Avanhandava. However, this pattern was not observed by Barbosa et al. (1999) in the Tietê system. The latter authors demonstrated that approximately 20 years after the Matsumura-Tundisi et al. (1981) study, the reservoirs downstream of Barra Bonita had a higher trophic level than that reported in the earlier study.

Increased agricultural and industrial activity allied with intensive use and occasional spillage of agrotoxic and toxic substances in general in the vicinity of aquatic ecosystems have caused river, dam and pond contamination worldwide. In response, several water quality programs have been implemented, involving methods of chemical, physical, and biological analysis. While such analyses reveal the contents of chemical substances in absolute quantities, they cannot identify fractions responsible for toxic effects in organisms. To expand these studies, ecotoxicological evaluations have been made in recent decades to investigate the effects of pollutants on the aquatic biota (Rand et al., 1995).

The present work was designed to evaluate the water and sediment quality of the Tietê River's series of dams through limnological analyses and toxicity bioassays with microcrustaceans and fish larvae as test organisms, in order to better evaluate the impacts currently affecting this system.

\section{MATERIAL AND METHODS}

Our study involved an evaluation of 15 sampling stations (see Fig. 1): station 1 (Tietê River) and station 2 (Piracicaba River); stations 3 and 4 upstream and downstream, respectively, from the Barra Bonita dam; stations 6 and 7 (Bariri); stations 9 and 10 (Ibitinga); stations 10 and 11 (Promissão); stations 12 and 13 (Nova Avanhandava); and stations 14 and 15 (Três Irmãos). Samples were also taken 


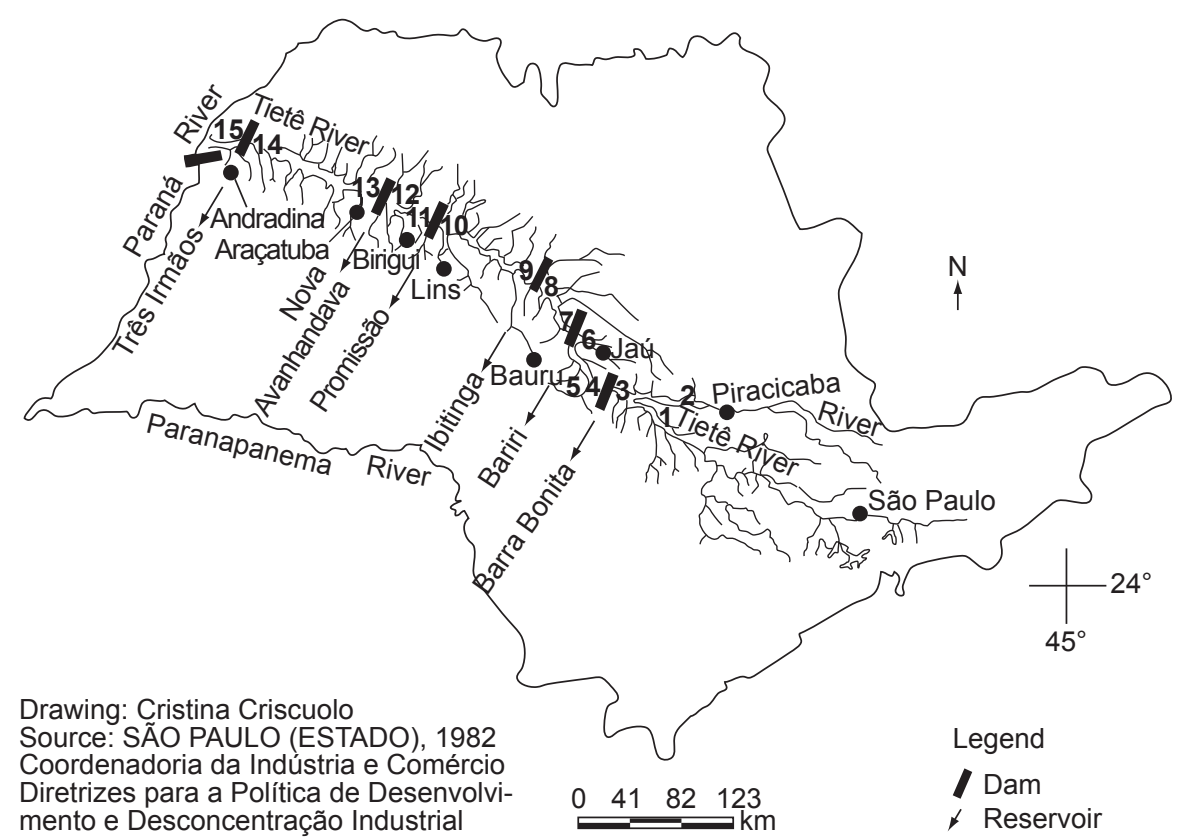

Fig. 1 - Location of sampling stations in the reservoirs of the middle and lower Tietê River.

from the Bauru River (station 5), a highly impacted tributary and, consequently, a significant source of pollutants for the water of Bariri Reservoir.

Sampling was carried out in two different periods: February and July of 2000, representing, respectively, the rainy (February) and dry (July) seasons. Water transparency was measured using a Secchi disk. A single vertically integrated sample of water was collected with a suction pump from each sampling station. Temperature, $\mathrm{pH}$, conductivity and dissolved oxygen were measured at $0.5 \mathrm{~m}$ depth intervals using a Horiba U-10 field meter. Water samples were transferred to previously washed and dried plastic bottles and stored at $4{ }^{\circ} \mathrm{C}$ until the moment they were analyzed. Total organic nitrogen (Golterman et al., 1978), total phosphorus (Standard Methods, 1995), total cadmium, chromium, copper and zinc (Standard Methods, 1995), as well as total suspended matter (Teixeira et al., 1978) were analyzed.

Sediment samples were collected with an Eckman dredge and immediately stored in plastic containers inside styrofoam boxes containing ice until their analysis in the laboratory. Analyses were made of the organic matter (Fonseca, 1997), granulometry (ABNT, 1968), and concentration of potentially bioavailable metals $(\mathrm{Cd}, \mathrm{Cr}, \mathrm{Cu}$ and $\mathrm{Zn})$ (Tessier \& Campbell, 1987).
For the bioassays, the sediment samples were kept refrigerated at $4{ }^{\circ} \mathrm{C}$ prior to the experiments. The toxicity bioassays were conducted with the test organisms Daphnia similis and Ceriodaphnia dubia (Crustacea, Cladocera) neonates and with Danio rerio (Cypriniforme, Cyprinidae) larvae. The test organisms used in the toxicity bioassays were kept according to the recommendations of CETESB (1991a).

The acute toxicity bioassays were conducted with water samples collected at different sampling stations. Newborn Daphnia similis were exposed to undiluted water and the immobile organisms counted after $48 \mathrm{~h}$. Acute toxicity bioassays were considered valid when the immobile individuals among the organisms in the control treatment did not exceed 10\% (CETESB, 1991a). For the chronic toxicity bioassays of water samples, newborn Ceriodaphnia dubia, 1 per test tube, were exposed to $15 \mathrm{~mL}$ of undiluted water in 10 test tubes for each sampling station. The bioassay lasted from seven to ten days, the period required for the third brood to hatch, and the number of newborns produced throughout the experiment was recorded (CETESB, 1991b).

The acute toxicity bioassays were conducted with Daphnia similis in sediment samples. Chronic toxicity bioassays were done with 
Ceriodaphnia dubia and Danio rerio larvae (24 h after hatching), following the protocol of Burton \& Macpherson (1995), which calls for a 1:4 ratio of sediment and water. The duration and the parameter evaluated in the acute and chronic toxicity bioassays with zooplankton were similar to those described for the water samples. The fish larvae bioassays lasted seven days, during which the organisms fed on nothing but their own vitelluses.

The following criteria were adopted to evaluate the results of the acute toxicity bioassays with Daphnia similis: a) nontoxic sample: immobility in the test organisms ranging from 0 to $10 \%$ of the test; b) toxicity trace: immobility ranging from 10 to $40 \%$ in test organisms, and c) toxic: immobility equal to or above $40 \%$ of the organisms (Barbosa, 2000). The results of the chronic toxicity bioassays for Ceriodapnhia dubia were analyzed for normality. Tukey's test (parametric) was applied for normal distributions, while the Kruskall-Wallis test (nonparametric) was applied to verify the occurrence of each sample's significant differences in relation to the control.

As for the organism Danio rerio, the toxicity evaluation of the environmental samples was based on the mortality percentage proposed by Prater \& Anderson (1977), which considers that mortality percentages of 1 to $25 \%$ indicate low environmental toxicity; 26 to $50 \%$ : medium toxicity, and 51 to 100\%: high toxicity.

Pearson correlation analyses were applied to detect correlations between metal concentrations in the water and sediment, and between the results of acute and chronic toxicity bioassays.

\section{RESULTS}

Table 1 lists the results of physicochemical variables monitored in the reservoirs' water samples. The water temperature revealed two very defined stations during the study period. The temperatures during the rainy period (Feb 2000) were higher, i.e., a minimum of $24.48{ }^{\circ} \mathrm{C}$ in the Piracicaba River and a maximum of $28.03{ }^{\circ} \mathrm{C}$ in Três Irmãos upstream. During the dry period (Jul 2000), the lowest temperature was $19{ }^{\circ} \mathrm{C}$ in the Piracicaba River and the highest temperature recorded was $22.78^{\circ} \mathrm{C}$ in Três Irmãos upstream.

With regard to $\mathrm{pH}$, the lowest values were found in Feb 2000, varying from 5.65 to 6.70,

TABLE 1

Average values of the physicochemical variables in the water column of the dams in the Tietê River.

\begin{tabular}{|c|c|c|c|c|c|c|c|c|}
\hline \multirow[t]{3}{*}{ Sampling stations } & \multicolumn{2}{|c|}{$\begin{array}{c}\text { Temperature } \\
\left({ }^{\circ} \mathbf{C}\right)\end{array}$} & \multicolumn{2}{|c|}{ pH } & \multicolumn{2}{|c|}{$\begin{array}{l}\text { Cond. } \\
(\mu \mathrm{S} / \mathrm{cm})\end{array}$} & \multicolumn{2}{|c|}{$\begin{array}{c}\text { Oxygen } \\
\text { Dissolved }(\mathrm{mg} / \mathrm{L})\end{array}$} \\
\hline & \multicolumn{8}{|c|}{ year 2000} \\
\hline & Feb & Jul & Feb & Jul & Feb & Jul & Feb & Jul \\
\hline Tietê River & 24.73 & 19.91 & 5.90 & 6.73 & 127 & 411 & 7.92 & 3.31 \\
\hline Piracicaba River & 24.48 & 19.00 & 5.96 & 6.12 & 64 & 245 & 8.04 & 1.25 \\
\hline Barra Bonita upstream & 25.61 & 19.41 & 6.10 & 6.56 & 126 & 239 & 7.67 & 5.85 \\
\hline Barra Bonita downstream & 24.62 & 20.01 & 6.15 & 6.71 & 111 & 219 & 7.90 & 5.32 \\
\hline Bauru River & 25.23 & 20.32 & 5.84 & 6.28 & 98 & 170 & 7.85 & 2.63 \\
\hline Bariri upstream & 25.29 & 20.28 & 5.92 & 6.22 & 118 & 117 & 7.67 & 9.98 \\
\hline Bariri downstream & 25.81 & 20.65 & 6.41 & 6.34 & 173 & 174 & 8.33 & 6.57 \\
\hline Ibitinga upstream & 26.18 & 21.26 & 5.92 & 6.82 & 178 & 114 & 8.14 & 8.97 \\
\hline Ibitinga downstream & 26.18 & 20.30 & 5.65 & 6.07 & 116 & 110 & 7.70 & 7.61 \\
\hline Promissão upstream & 26.55 & 21.26 & 6.34 & 6.82 & 101 & 114 & 7.95 & 8.97 \\
\hline Promissão downstream & 26.94 & 21.50 & 6.70 & 7.13 & 98 & 115 & 7.55 & 8.61 \\
\hline Nova Avanhandava upstream & 26.96 & 21.42 & 6.47 & 6.99 & 84 & 125 & 7.83 & 8.98 \\
\hline Nova Avanhandava downstream & 27.94 & 21.20 & 6.58 & 6.64 & 82 & 123 & 7.30 & 8.59 \\
\hline Três Irmãos upstream & 28.03 & 22.41 & 6.46 & 6.78 & 62 & 86 & 7.49 & 8.70 \\
\hline Três Irmãos downstream & 27.82 & 22.78 & 6.54 & 6.95 & 58 & 51 & 7.17 & 8.44 \\
\hline Conama 20/1986 Category 2 rivers & & & & & & & & \\
\hline
\end{tabular}

The values in bold exceed the maximum limit established by CONAMA Resolution 20/1986 for Category 2 rivers. 
respectively, in Ibitinga and Promissão, both downstream, while the lowest $\mathrm{pH}$ in July 2000 was 6.07 (Ibitinga downstream) and the highest was 7.13 (Promissão downstream). The $\mathrm{pH}$ values below or close to the lower limit established by CONAMA 20/1986 were found in the rainy season in the Tietê, Piracicaba and Bauru rivers and in Bariri and Promissão reservoirs. Water conductivity showed the highest values in July 2000 , with a minimum of $51 \mu \mathrm{S} / \mathrm{cm}$ (Três Irmãos downstream) and a maximum of $411 \mu \mathrm{S} / \mathrm{cm}$ (Tietê River). The lowest values were recorded in the rainy period, with a minimum of $58 \mu \mathrm{S} / \mathrm{cm}$ in Três Irmãos downstream and a maximum of $178 \mu \mathrm{S} / \mathrm{cm}$ in Ibitinga upstream.

The dissolved oxygen concentrations were higher in Feb 2000 at most of the sampling stations, with a minimum concentration of $7.17 \mathrm{mg} / \mathrm{L}$ (Três Irmãos downstream) and a maximum of $8.33 \mathrm{mg} / \mathrm{L}$ (Bariri downstream). In July 2000, the lowest concentration was $1.25 \mathrm{mg} / \mathrm{L}$ (Piracicaba River) and the highest was $9.98 \mathrm{mg} / \mathrm{L}$ in Bariri upstream. In July 2000, low dissolved oxygen concentrations were also found in the Tietê $(3.31 \mathrm{mg} / \mathrm{L})$ and Bauru $(2.63 \mathrm{mg} / \mathrm{L})$ river water and in Barra Bonita reservoir upstream $(5.85 \mathrm{mg} / \mathrm{L})$. These values fell below those established by CONAMA Resolution 20/1986 for category 2 (5-9 $\mathrm{mg} / \mathrm{L})$ rivers.

As for the Secchi disk results, the best visibility at most of the sampling stations was found in the dry period, with a minimum of $0.35 \mathrm{~m}$ in the Piracicaba River and a maximum of $9.3 \mathrm{~m}$ in the Três Irmãos reservoir. The lowest values were recorded in the rainy season $(0.1 \mathrm{~m}$ to $3.5 \mathrm{~m})$ in the Piracicaba River and upstream and the downstream, respectively, from Nova Avanhandava dam. The values of total suspended matter were inversely related to the visibility obtained by Secchi disk: higher concentrations of total suspended matter in the rainy season caused lower visibility values obtained by Secchi disk (Fig. 2).

As for total organic nitrogen, the Tietê River water consistently showed the highest concentrations, and the highest values were generally

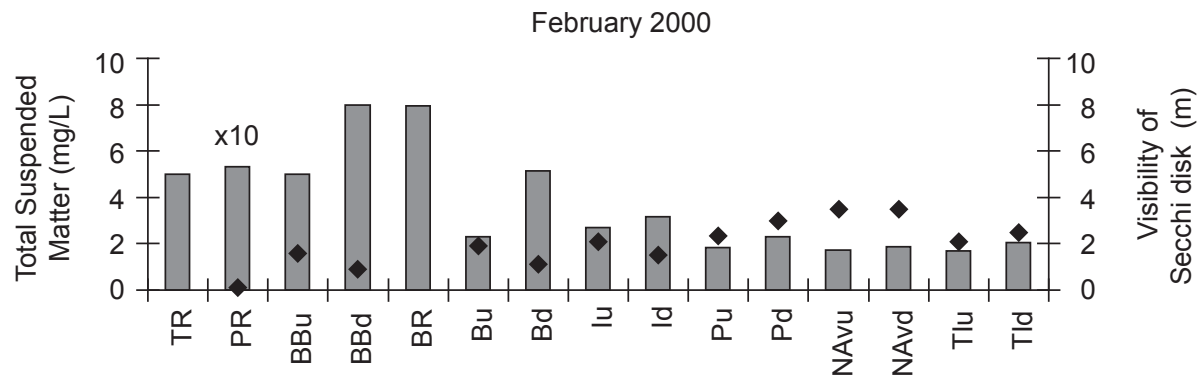

July 2000

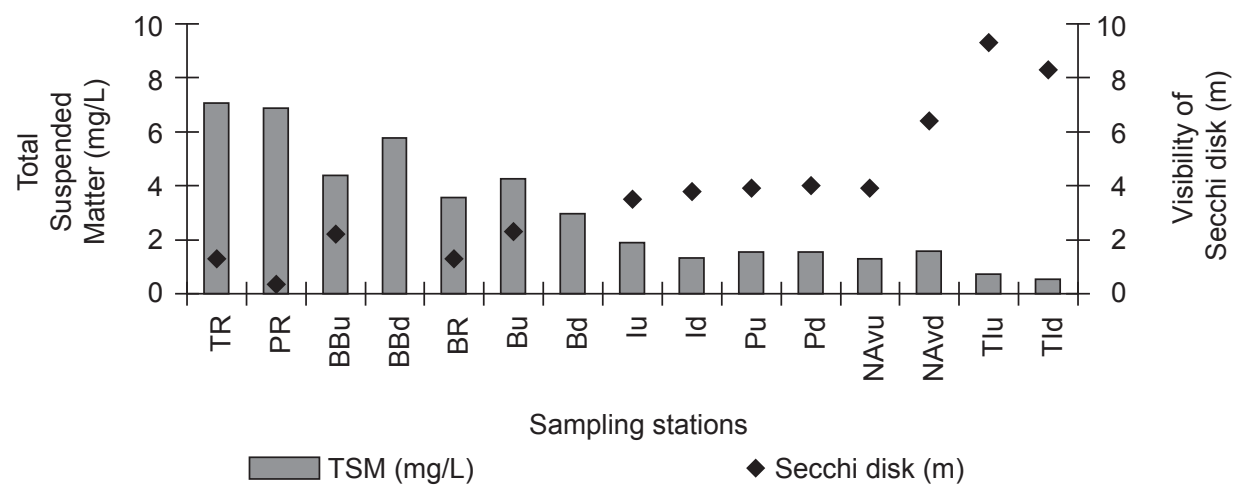

Fig. 2 - Variation of total suspended matter and visibility of the Secchi disk of the reservoirs of the Tietê River. 
found in July 2000, varying from $0.093 \mathrm{mg} / \mathrm{L}$ to $5.32 \mathrm{mg} / \mathrm{L}$ (Nova Avanhandava upstream and in Tietê River, respectively). The lowest concentrations were found in Feb 2000 (from $0.05 \mathrm{mg} / \mathrm{L}$ to $1.77 \mathrm{mg} / \mathrm{L}$, in Nova Avanhandava and Três Irmãos reservoirs and in the Tietê River, respectively) (Fig. 3).

As Fig. 4 indicates, the highest total phosphorus concentrations were recorded in the wet season (Feb 2000), with values varying from $0.02 \mathrm{mg} / \mathrm{L}$ to $0.23 \mathrm{mg} / \mathrm{L}$ (Três Irmãos upstream and Barra Bonita downstream, respectively). The concentrations in most of the sampling stations were lowest in July 2000 (from $0.01 \mathrm{mg} / \mathrm{L}$ to $0.75 \mathrm{mg} / \mathrm{L}$, Promissão downstream to Piracicaba River, respectively). In Feb 2000, all the values exceeded the limit established by CONAMA Resolution 20/1986 (0.02 mg/L) except for Três Irmãos upstream, while in July 2000, total phosphorus exceeding the limit included the sampling stations of the Tietê River downstream to the Ibitinga reservoir.

As for the total metal concentrations in the water (Table 2), cadmium exceeded the limit established by CONAMA Resolution 20/1986 for Category 2 rivers. Higher values were recorded in July $(0.004 \mathrm{mg} / \mathrm{L}$ to $0.013 \mathrm{mg} / \mathrm{L}$, for Ibitinga and Promissão reservoirs and the Piracicaba River, respectively) and the lowest concentrations ( $0.002 \mathrm{mg} / \mathrm{L}$ to $0.009 \mathrm{mg} / \mathrm{L}$ ) were found in the Tietê River and Barra Bonita reservoir, respectively) in

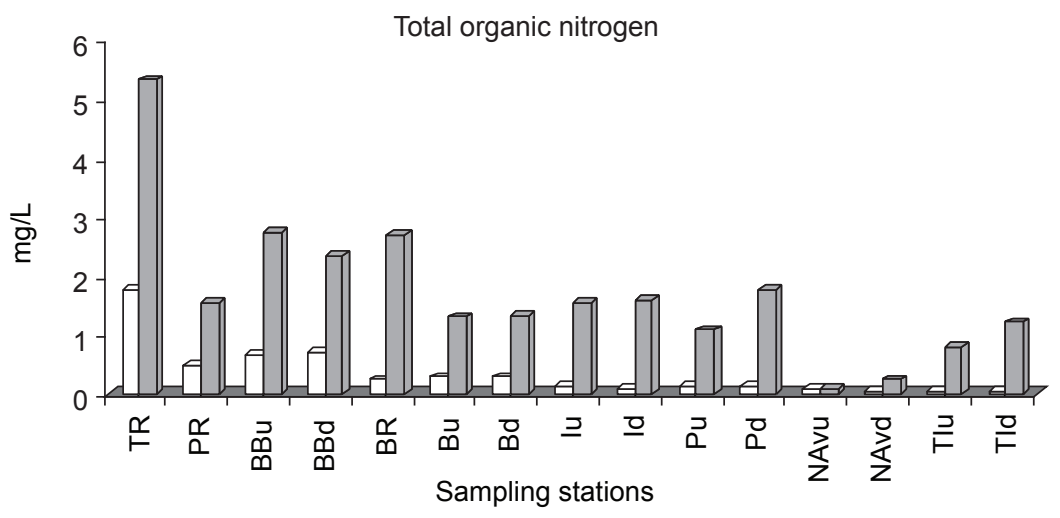

$\square$ February 2000

July 2000

Fig. 3 - Variation of total organic nitrogen in the water samples from the reservoirs of the Tietê River.

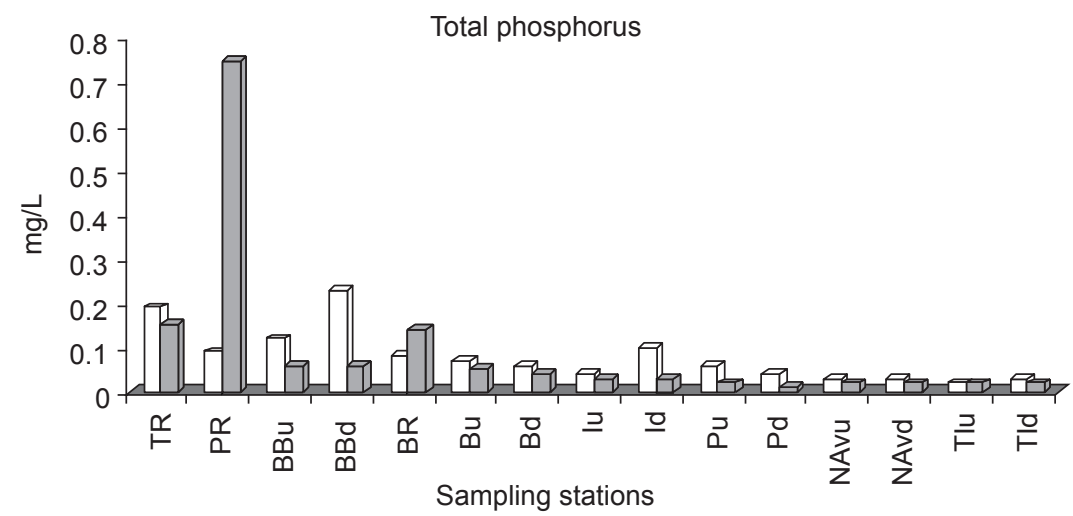

$\square$ February 2000

$\square$ July 2000

Fig. 4 - Variation of the total phosphorus values in the water samples of the reservoirs in the Tietê River. 
TABLE 2

Total metal concentrations in the water samples from the dams in the Tietê River and limits established by CONAMA Resolution 20/1986 for Category 2 rivers.

\begin{tabular}{|c|c|c|c|c|c|c|c|c|}
\hline \multirow[t]{3}{*}{ Sampling stations } & \multicolumn{2}{|c|}{$\begin{array}{c}\text { Cadmium } \\
(\mathrm{mg} / \mathrm{L})\end{array}$} & \multicolumn{2}{|c|}{$\begin{array}{c}\text { Chromium } \\
(\mathrm{mg} / \mathrm{L})\end{array}$} & \multicolumn{2}{|c|}{$\begin{array}{l}\text { Copper } \\
(\mathrm{mg} / \mathrm{L})\end{array}$} & \multicolumn{2}{|c|}{$\begin{array}{c}\text { Zinc } \\
(\mathrm{mg} / \mathrm{L})\end{array}$} \\
\hline & \multicolumn{8}{|c|}{ year 2000} \\
\hline & Feb & Jul & Feb & Jul & Feb & Jul & Feb & Jul \\
\hline Tietê River & 0.002 & 0.007 & $\mathrm{ND}$ & 0.008 & 0.0082 & 0.011 & 0.035 & 0.012 \\
\hline Piracicaba River & ND & 0.013 & 0.056 & ND & ND & 0.005 & 1.215 & 0.015 \\
\hline Barra Bonita Dam & 0.009 & 0.005 & $\mathrm{ND}$ & ND & ND & 0.004 & 0.119 & 0.002 \\
\hline Bauru River & ND & 0.007 & ND & ND & ND & $\mathrm{ND}$ & 0.096 & 0.043 \\
\hline Bariri Dam & 0.002 & 0.008 & ND & ND & ND & 0.003 & 0.052 & 0.021 \\
\hline Ibitinga Dam & ND & 0.004 & ND & $\mathrm{ND}$ & ND & 0.001 & 0.042 & 0.011 \\
\hline Promissão Dam & $\mathrm{ND}$ & 0.004 & ND & ND & ND & 0.003 & 0.069 & 0.010 \\
\hline Nova Avanhandava Dam & 0.005 & 0.008 & ND & ND & ND & 0.007 & 0.047 & 0.009 \\
\hline Três Irmãos Dam & 0.007 & 0.008 & ND & $\mathrm{ND}$ & ND & ND & 0.075 & 0.012 \\
\hline $\begin{array}{l}\text { CONAMA 20/1986 } \\
\text { Category } 2 \text { rivers }\end{array}$ & \multicolumn{2}{|c|}{0.001} & \multicolumn{2}{|c|}{0.05} & \multicolumn{2}{|c|}{0.02} & \multicolumn{2}{|c|}{0.18} \\
\hline
\end{tabular}

$\mathrm{ND}=$ not detected. The values in bold exceed the maximum limit established by CONAMA Resolution 20/1986 for Category 2 rivers.

Feb 2000. Chromium exceeded the limit established by CONAMA in Feb 2000 in the Piracicaba River $(0.056 \mathrm{mg} / \mathrm{L})$, while copper concentrations were lower than the legal limit. The lowest zinc concentration was $0.035 \mathrm{mg} / \mathrm{L}$ in the Tietê River and the highest $-1.215 \mathrm{mg} / \mathrm{L}$ - was found in Feb 2000 in the Piracicaba River (exceeding CONAMA's limit for Class 2 rivers, i.e., above $0.18 \mathrm{mg} / \mathrm{L}$ ).

The lowest concentrations of organic matter in sediment were found in Feb 2000, varying from $0.1 \%$ (in Nova Avanhandava reservoir downstream) to $15.34 \%$ (in the Bauru River). In July 2000, these concentrations varied from $0.5 \%$ (upstream and downstream from the Três Irmãos Dam) to $16.73 \%$ (in Promissão reservoir upstream). As for granulometry, there was a prevalence of clay and silt in the Tietê and Piracicaba Rivers and in the Barra Bonita to Promissão reservoirs, while sand was prevalent in the Nova Avanhandava and Três Irmãos reservoirs (Table 3).

Our findings for potentially bioavailable metals in the sediment are listed in Table 4. In July 2000, the highest values were found for cadmium $(1.67 \mathrm{mg} / \mathrm{Kg}$ to $5.00 \mathrm{mg} / \mathrm{Kg}$ (in the Tietê and Bauru rivers, respectively), copper $(3.33 \mathrm{mg} / \mathrm{Kg}$ to $97.57 \mathrm{mg} / \mathrm{Kg}$, in Nova Avanhandava and Bariri reservoirs, respectively), and zinc $(1.60 \mathrm{mg} / \mathrm{Kg}$ to $224.93 \mathrm{mg} / \mathrm{Kg}$, in Três Irmãos reservoir and the Tietê River, respectively). In Feb 2000, the highest chromium concentrations detected varied from $3.60 \mathrm{mg} / \mathrm{Kg}$ (Barra Bonita reservoir) to $11.40 \mathrm{mg} / \mathrm{Kg}$ (Piracicaba River).

In Feb 2000, Daphnia similis showed acute toxicity when exposed to a water sample from downstream Bariri and upstream Nova Avanhandava, as was the case in July 2000 with the water samples from upstream Promissão to downstream Nova Avanhandava. A statistical analysis of reproduction data from the chronic toxicity bioassays with Ceriodaphnia dubia revealed chronic effects on the test organisms exposed to water samples from the Tietê (Feb and Jul 2000), Piracicaba River (Feb 2000), upstream Barra Bonita reservoir (Feb and Jul 2000), downstream Barra Bonita (Feb 2000), Bauru River (Feb 2000), upstream Bariri (Feb and Jul 2000), downstream Bariri (Feb 2000), upstream Ibitinga (Feb 2000) and upstream Promissão (Feb and Jul 2000) (Table 5).

The toxicity bioassays on sediment samples showed acute toxicity for $D$. similis in sediment from downstream Ibitinga and upstream Promissão reservoirs in Feb 2000, and chronic toxicity for $C$. dubia exposed to sediment from the Tietê river (Feb and Jul 2000) and the reservoirs from Barra Bonita to Ibitinga (Feb 2000). Danio rerio displayed acute toxicity in sediments from the Tietê and Piracicaba 
TABLE 3

Percentage of organic matter and granulometry of sediment samples from the dams in the Tietê River.

\begin{tabular}{|c|c|c|c|c|c|c|c|c|}
\hline \multirow[t]{3}{*}{ Sampling stations } & \multicolumn{2}{|c|}{ Organic matter $(\%)$} & \multicolumn{2}{|c|}{ Sand $(\%)$} & \multicolumn{2}{|c|}{ Silt $(\%)$} & \multicolumn{2}{|c|}{ Clay $(\%)$} \\
\hline & \multicolumn{8}{|c|}{ year 2000} \\
\hline & Feb & Jul & Feb & Jul & Feb & Jul & Feb & Jul \\
\hline Tietê River & 13.92 & 13.56 & 17 & 23 & 12 & 17 & 70 & 60 \\
\hline Piracicaba River & 10.92 & 11.47 & 19 & 32 & 16 & 21 & 65 & 47 \\
\hline Barra Bonita upstream & 12.60 & 12.49 & 15 & 26 & 85 & 47 & 0 & 27 \\
\hline Barra Bonita downstream & 7.90 & 2.32 & - & 26 & - & 13 & - & 0 \\
\hline Bauru River & 15.34 & 13.51 & 30 & 20 & 70 & 20 & 0 & 60 \\
\hline Bariri upstream & 14.35 & 14.82 & 49 & 30 & 51 & 20 & 0 & 50 \\
\hline Bariri downstream & 11.55 & 0.30 & 30 & 77 & 70 & 0 & 0 & 3 \\
\hline Ibitinga upstream & 9.99 & 10.49 & 12 & 35 & 88 & 30 & 0 & 35 \\
\hline Ibitinga downstream & 11.13 & 13.65 & 28 & 47 & 72 & 33 & 0 & 20 \\
\hline Promissão upstream & 12.06 & 16.73 & 19 & 67 & 81 & 20 & 0 & 13 \\
\hline Promissão downstream & 0.70 & 4.07 & 77 & 80 & 23 & 17 & 0 & 3 \\
\hline Nova Avanhandava upstream & 12.80 & 0.50 & 84 & 92 & 84 & 6 & 0 & 2 \\
\hline Nova Avanhandava downstream & 0.10 & 5.83 & - & 69 & - & 20 & - & 11 \\
\hline Três Irmãos upstream & 0.30 & 0.50 & 100 & 92 & 0 & 5 & 0 & 3 \\
\hline Três Irmãos downstream & 0.50 & 0.50 & 97 & 96 & 0 & 3 & 3 & 1 \\
\hline
\end{tabular}

TABLE 4

Potentially bioavailable metals in the sediment samples from the dams in the Tietê River.

\begin{tabular}{|c|c|c|c|c|c|c|c|c|}
\hline \multirow[t]{3}{*}{ Sampling stations } & \multicolumn{2}{|c|}{ Cadmium (mg/kg) } & \multicolumn{2}{|c|}{ Chromium (mg/kg) } & \multicolumn{2}{|c|}{ Copper (mg/kg) } & \multicolumn{2}{|c|}{ Zinc (mg/kg) } \\
\hline & \multicolumn{8}{|c|}{ year 2000} \\
\hline & Feb & Jul & Feb & Jul & Feb & Jul & Feb & Jul \\
\hline Tietê River & 0.80 & 1.67 & 6.20 & 11.67 & 16.00 & 62.33 & 69.14 & 224.93 \\
\hline Piracicaba River & 0.80 & 2.87 & 11.40 & 6.33 & 22.80 & 45.00 & 62.94 & 139.37 \\
\hline Barra Bonita Dam & 0.80 & 3.00 & 3.60 & $\mathrm{ND}$ & 18.80 & 70.33 & 38.46 & 122.07 \\
\hline Bauru River & 1.00 & 5.00 & 9.80 & ND & 39.60 & 95.33 & 69.02 & 163.33 \\
\hline Bariri Dam & 1.00 & 2.00 & 6.40 & ND & 29.00 & 97.57 & 31.54 & 106.8 \\
\hline Ibitinga Dam & 0.60 & 2.67 & 9.00 & ND & 20.40 & 68.67 & 16.58 & 51.13 \\
\hline Promissão Dam & 0.60 & 2.67 & 6.60 & ND & 15.80 & 39.33 & 3.26 & 32.97 \\
\hline Nova Avanhandava Dam & 1.60 & 4.33 & 7.80 & ND & 35.60 & 3.33 & 6.56 & 2.20 \\
\hline Três Irmãos Dam & 1.80 & 3.33 & ND & ND & 0.80 & 4.67 & 1.52 & 1.60 \\
\hline
\end{tabular}

rivers (Feb and Jul 2000) and the Bauru (Jul 2000), and from Barra Bonita reservoir upstream and downstream (Feb and Jul 2000), Bariri upstream (Feb and Jul 2000) and Ibitinga downstream (Jul 2000) (Table 6).

An analysis of the correlation between metal concentrations and bioassayed toxicity revealed that cadmium, copper and zinc concentrations in the sediment correlated positively $(r>0.5$ and $p<0.05)$ with the data from chronic toxicity bioassays on sediment samples. However, no correlation was found between metal concentrations and acute and chronic toxicity in water samples $(\mathrm{r}<0.5$ and $\mathrm{p}>0.05)$. 
TABLE 5

Percentage of immobility of neonates of Daphnia similis obtained in acute toxicity bioassays and result of the Kruskall-Wallis test for the data on Ceriodaphnia dubia reproduction in the chronic toxicity bioassay when exposed to samples of water from the dams in the Tietê River.

\begin{tabular}{|c|c|c|c|c|}
\hline \multirow{2}{*}{ Sampling stations } & \multicolumn{2}{|c|}{ February 2000} & \multicolumn{2}{|c|}{ July 2000} \\
\hline & D. similis (\%) & C dubia & D. similis (\%) & C dubia \\
\hline Laboratory control & $5(\mathrm{TA})$ & 147 & $5(\mathrm{TA})$ & 146 \\
\hline Tietê River & $0(\mathrm{NT})$ & $33 *$ & $30(\mathrm{TT})$ & 0* \\
\hline Piracicaba River & $0(\mathrm{NT})$ & $25^{*}$ & $0(\mathrm{NT})$ & 111 \\
\hline Barra Bonita upstream & $0(\mathrm{NT})$ & $10 *$ & $10(\mathrm{NT})$ & 0* \\
\hline Barra Bonita downstream & $0(\mathrm{NT})$ & $12 *$ & $0(\mathrm{NT})$ & 43 \\
\hline Bauru River & $5(\mathrm{NT})$ & $25^{*}$ & $0(\mathrm{NT})$ & 23 \\
\hline Bariri upstream & $0(\mathrm{NT})$ & $36^{*}$ & $0(\mathrm{NT})$ & 0* \\
\hline Bariri downstream & $100(T)$ & $10 *$ & $0(\mathrm{NT})$ & 39 \\
\hline Ibitinga upstream & $0(\mathrm{NT})$ & $32 *$ & $13(\mathrm{TT})$ & 142 \\
\hline Ibitinga downstream & $20(\mathrm{TT})$ & 119 & $6(\mathrm{NT})$ & 145 \\
\hline Promissão upstream & $0(\mathrm{NT})$ & $36^{*}$ & $100(\mathrm{~T})$ & 0* \\
\hline Promissão downstream & $10(\mathrm{NT})$ & 53 & $93(\mathrm{~T})$ & 61 \\
\hline Nova Avanhandava upstream & $90(\mathbf{T})$ & 92 & $80(T)$ & 67 \\
\hline Nova Avanhandava downstream & $5(\mathrm{NT})$ & 122 & $73(T)$ & 111 \\
\hline Três Irmãos upstream & $0(\mathrm{NT})$ & 146 & 0 (NT) & 141 \\
\hline Três Irmãos downstream & $0(\mathrm{NT})$ & 142 & $0(\mathrm{NT})$ & 143 \\
\hline
\end{tabular}

D. similis: TA (test accepted), NT (nontoxic) $=$ immobility $\leq 10 \%$; TT (toxicity trace) $=10 \%<$ immobility $<40 \%$.

$\mathrm{T}$ (toxic) $=$ immobility $\geq 40 \%$.

C. dubia: *significant difference in relation to the control $(\mathrm{p}<0.05)$.

\section{DISCUSSION}

Reservoirs built in cascade arrangements to generate electricity are usually operated as simple units, but from the standpoint of physical, chemical and biological characteristics, each reservoir can behave as a separate unit with unique characteristics, e.g., residence time, tributaries and usage of its hydrographic basin. However, understanding the limnology of a specific reservoir is not easy, particularly if it is one of a series, without first understanding the processes that take place in the chain of reservoirs located upstream from it (Straškraba, 1994).

According to Tundisi (1999), the main components and forces that govern the conditions in a reservoir operation, whose measuring is essential, include the area's climatic characteristics, the time of residence of the water, and the position of the reservoir (since a reservoir causes and receives effects from other reservoirs up and downstream from it).
In the reservoirs of the middle and lower Tietê river, for example, the contribution of suspended matter coming from the Tietê and Piracicaba rivers (precise sources) and from the reservoirs' banks (diffuse sources) in the wet season (Feb 2000) exceeds that of the dry season (Jul 2000). This seasonalness of matter generated by rainfall produces a pulse of nutrients and inorganic matter within the reservoirs, which is confirmed by the highest concentrations of suspended matter in the wet season causing the lowest Secchi disk visibility values in the reservoirs. The decreasing penetration of light revealed by Secchi disk measurements was attributed to the greater dispersion of suspended particulate matter (Wetzel, 1993).

With respect to spatial variations, a generally increasing gradient of water transparency was found along the cascade of reservoirs in the two sampled periods. This finding coincides with that of Tundisi et al. (1991) and Güntzel (2000) in the middle and low Tietê reservoirs. According to Straškraba (1994), in the upper reservoirs of the 
TABLE 6

Percentage of immobility of neonates of Daphnia similis and mortality of Danio rerio larvae in acute toxicity bioassays and result of the Kruskall-Wallis test for the data on Ceriodaphnia dubia reproduction in the chronic toxicity bioassay when exposed to the sediment samples from the dams in the Tietê River.

\begin{tabular}{|c|c|c|c|c|c|c|}
\hline \multirow[t]{2}{*}{ Sampling stations } & \multicolumn{3}{|c|}{ February 2000} & \multicolumn{3}{|c|}{ July 2000} \\
\hline & D. similis & C. dubia & D. rerio & D. similis & C. dubia & D. rerio \\
\hline Laboratory control & $2(\mathrm{TA})$ & 169 & $6.6(\mathrm{TA})$ & 3 (TA) & 154 & $6.6(\mathrm{TA})$ \\
\hline Tietê River & $0(\mathrm{NT})$ & 11* & $67(\mathrm{HT})$ & $0(\mathrm{NT})$ & 21* & $100(\mathrm{HT})$ \\
\hline Piracicaba River & $3(\mathrm{NT})$ & 76 & $60(\mathrm{HT})$ & $10(\mathrm{NT})$ & 52 & 90 (HT) \\
\hline Barra Bonita upstream & 7 (NT) & $12 *$ & $93(\mathrm{HT})$ & $5(\mathrm{NT})$ & $23 *$ & $100(\mathrm{HT})$ \\
\hline Barra Bonita downstream & $20(\mathrm{TT})$ & 50* & $60(\mathrm{HT})$ & $5(\mathrm{NT})$ & 113 & $60(\mathrm{HT})$ \\
\hline Bauru River & $10(\mathrm{NT})$ & $11 *$ & 33 (MT) & $0(\mathrm{NT})$ & 50 & $100(\mathrm{HT})$ \\
\hline Bariri upstream & $7(\mathrm{NT})$ & $28 *$ & $67(\mathrm{HT})$ & $0(\mathrm{NT})$ & 112 & $60(\mathrm{HT})$ \\
\hline Bariri downstream & $3(\mathrm{NT})$ & $45^{*}$ & 27 (MT) & $0(\mathrm{NT})$ & 67 & 20 (LT) \\
\hline Ibitinga upstream & $0(\mathrm{NT})$ & $20 *$ & 33 (MT) & $0(\mathrm{NT})$ & 35 & $10(\mathrm{LT})$ \\
\hline Ibitinga downstream & $60(T)$ & 139 & 33 (MT) & $0(\mathrm{NT})$ & 96 & $51($ HT) \\
\hline Promissão upstream & $50(\mathbf{T})$ & 126 & $43(\mathrm{MT})$ & $20(\mathrm{IT})$ & 101 & $20(\mathrm{LT})$ \\
\hline Promissão downstream & $10(\mathrm{NT})$ & 120 & $30(\mathrm{LT})$ & $10(\mathrm{NT})$ & 125 & $20(\mathrm{LT})$ \\
\hline Nova Avanhandava upstream & $25(\mathrm{TT})$ & 105 & 43 (MT) & 0 (NT) & 113 & $0(\mathrm{NT})$ \\
\hline Nova Avanhandava downstream & $0(\mathrm{NT})$ & 77 & 43 (MT) & $10(\mathrm{NT})$ & 123 & 10 (LT) \\
\hline Três Irmãos upstream & $30(\mathrm{TT})$ & 81 & $10(\mathrm{LT})$ & $10(\mathrm{NT})$ & 127 & $10(\mathrm{LT})$ \\
\hline Três Irmãos downstream & 20 (TT) & 85 & $7(\mathrm{LT})$ & $15(\mathrm{TT})$ & 149 & $0(\mathrm{NT})$ \\
\hline
\end{tabular}

D. similis: TA (test accepted), NT (nontoxic) = immobility $\leq 10 \%$; TT (toxicity trace) $=10 \%<$ immobility $<40 \%$.

T (toxic) $=$ immobility $\geq 40 \%$.

D. rerio: TA (test accepted), LT (low toxicity) $=1<$ mortality $<25 \%$; MT (medium toxicity) $=26<$ mortality

$<50 \%$, HT(high toxicity) $=51<$ mortality $<100 \%$.

C. dubia: *significant difference in relation to the control $(\mathrm{p}<0.05)$.

cascade system, the presence of abundant suspended matter causes decreased light penetration and, hence, lower visibility of the Secchi disk, which is not the case in the lower reservoirs, thanks to the sedimentation of suspended matter in the system's upper portion.

In terms of water temperature, the study period showed two well-defined seasons, with higher temperatures in the wet season (summer) and lower temperatures in the dry season (winter). The dissolved gas concentration in water is one of the most important environmental variables in the dynamics and characterization of aquatic ecosystems. This variable is influenced by seasonal alterations in rainfall, temperature, water flow, and retention time indices. The low dissolved oxygen concentrations found in the Tietê, Piracicaba and Bauru rivers and Barra Bonita reservoir in July 2000 indicated anoxia resulting from intensive decomposition of organic matter, which reduces oxygen concentrations.

Persistent anoxia is a negative factor in water quality because, under such conditions, the chemical compounds in sediment, as well as toxic gases, e.g., methane and hydrosulfide, tend to be released into the water (Esteves, 1988). In the Segredo reservoir, the second of a series of four reservoirs in the middle Iguaçu river (Paraná State), Thomaz et al. (1997) found anoxia occurring throughout most of the year, when the reservoir was thermally stratified. According to these authors, anoxic conditions can favor the release of phosphorus from sediment, contributing to the reservoir's eutrophication.

The values of $\mathrm{pH}$ were close to the limit established by CONAMA Resolution 20/1986 for Category 2 rivers in Feb 2000 in the Tietê, Piracicaba and Bauru rivers and in the Bariri and Promissão reservoirs. Aquatic ecosystems with 
low $\mathrm{pH}$ show high concentrations of organic acids. The lowest $\mathrm{pH}$ values were recorded in the wet season, demonstrating the seasonal influence on the system's $\mathrm{pH}$, since rainwater is usually acid (pH 5-6) and can also affect the $\mathrm{pH}$ of aquatic ecosystems (Esteves, 1988).

Conductivity was higher in the dry season, with the lowest values recorded in the wet season. Seasonal variations in this variable were attributed to diluted ion concentrations resulting from higher rainfall in the wet season, resulting in the lowest conductivity values, a phenomenon not found in the dry season. Güntzel (2000) found high conductivity values in the 1998 rainy season in the same reservoirs, ascribing this finding to greater input of nutrients and sediment, resulting in higher dissolved ion concentrations in the water. A generally high concentration of ions was found in the Tietê River and in the first two reservoirs of the cascade (Barra Bonita and Bariri), and high deposition and consumption along the series of reservoirs in Jul 2000, although some intermediary reservoirs showed higher values than those found in February in the Tietê River.

Thomaz et al. (1997) found low electric conductivity values in July and August and high values in January in the Segredo reservoir (Paraná River), which ranged from $20 \mu \mathrm{S} / \mathrm{cm}$ to $50 \mu \mathrm{S} / \mathrm{cm}$. In the cascading reservoirs of the São Francisco River, Severi et al. (2000) found conductivity values varying from $62 \mu \mathrm{S} / \mathrm{cm}$ to $74 \mu \mathrm{S} / \mathrm{cm}$.

Nutrient concentrations were also related to conductivity. The total organic nitrogen concentrations were generally higher in the dry season, which may be attributed to greater water retention in the reservoirs and, hence, to higher nitrogen compound concentrations. The lowest values were found in the wet season, evidencing the diluting effect of rainwater flowing into the system. During the period of this study, high total organic nitrogen concentrations were detected in the reservoirs of the middle and lower Tietê, in the Tietê, Piracicaba and Bauru rivers, and in the cascade system's upper reservoirs. In the wet season of 1999 , Barbosa et al. (1999) also found lower nitrogen concentrations in the Tietê River than in the Barra Bonita Reservoir.

As for total phosphorus, the wet season showed higher concentrations than the dry season. The highest concentrations were found in the
Tietê and Piracicaba rivers and in the reservoirs from Barra Bonita down to Promissão. Thus, a comparison of the legal limits and the values found in this study indicates that most of the latter exceeded the limit, mainly in the upper and middle portion of the cascade system, indicating the reservoirs' eutrophication.

As for the absence of a decrease in total phosphorus concentrations found throughout the cascade system studied here, Sandes (1990) also found higher phosphorus concentrations in the Bariri reservoir than in Barra Bonita reservoir. The presence of easily identifiable sources (domestic and industrial waste) and diffuse sources (agricultural activities) of discharge into the drainage basin, as well as favorable conditions for sediment resuspension, likely contributed to this finding. Barbosa et al. (1999) noted high total phosphorus concentrations in the Tietê River $(0.28 \mathrm{mg} / \mathrm{L})$, and a decrease in this nutrient in the first reservoir of the series $(0.06 \mathrm{mg} / \mathrm{L})$, followed by an increase in the second reservoir $(0.09 \mathrm{mg} / \mathrm{L})$ and a decrease throughout the other reservoirs.

In the cascade reservoirs of the lower San Francisco River, Rocha et al. (2000) found retention of nutrients in the lateral parts of the system; however, the central body did not show such retention due to the low retention time and to suspended matter. According to these authors, the system as a whole acts to conserve the physical, biological and chemical characteristics, and visible alterations in the water were not seen from the beginning to the end of the cascade. However, that was not the case in the middle and lower Tietê reservoirs.

Metals are extremely important elements in aquatic ecosystems because, albeit essential in small concentrations, many are toxic at high levels, and can bioaccumulate and biomagnify in food webs, ultimately presenting risks to predators at the top of the food chain, including humans. In the present study, total metals concentrations in water were close to or exceeded the limits established by CONAMA Resolution 20/1986 for Category 2 rivers. Our findings indicated metal contamination in both water and sediment caused by domestic sewage and industrial and agricultural effluents flowing into these aquatic ecosystems.

Metals are also significant pollutants of aquatic sediments. The highest potentially bioavailable 
metal concentrations were found in the Tietê, Piracicaba and Bauru rivers, demonstrating anthropic influence and foreshadowing its consequences on the environmental quality of the Tietê reservoirs. These values showed a rising tendency over time, indicating that these reservoirs are undergoing a process of deterioration (Esteves et al., 1981). The Pearson correlation revealed a significant correlation between cadmium, copper and zinc in the sediment and in the chronic toxicity bioassays.

As for potentially bioavailable metals in the sediment, the cascade of reservoirs showed a decreasing gradient of zinc concentrations. On the other hand, cadmium and chromium were found to increase from Barra Bonita reservoir towards Nova Avanhandava and Três Irmãos reservoirs, likely because of diffuse sources of pollution in the lower reservoirs.

Another important factor is the bioavailability of metals. The prevalence of clay and silt fractions over sand and the higher percentages of organic matter in the cascade's upper reservoirs may lead to a large number of connection loci to metals. Because of their large superficial area to volume ratio, fine-textured sediments (containing high percentages of clay and silt) have a greater capacity to retain chemicals than do thicker-textured sediments containing fewer metals connection loci (Rand et al., 1995)

The toxicity bioassays indicated that a large proportion of the water and sediment samples collected in Feb 2000 caused toxic effects in the test organisms, possibly resulting from the input of abundant matter from the surrounding areas into the reservoirs. Despite the high total metal concentrations in the water and potentially bioavailable in the Tietê and Piracicaba river sediment and in that of the upper reservoirs of the Tietê cascade system, no acute effects on Daphnia similis were recorded for those stations, while the chronic toxicity tests with Ceriodaphnia dubia and Danio rerio indicated a decrease in toxicity along the cascade. According to Cooney (1995), really significant differences have been found among different groups of organisms, and many authors have recently suggested that pollutants should be tested on algae, on one or more invertebrate groups, or on fish in order to get the most complete picture of existing toxicity.
Using Ceriodaphnia silvestrii (a native species) and Daphnia similis to evaluate the quality of water in the Piracicaba River basin, Fonseca (1997) also found considerable differences among the tested species when exposed to a water sample with high zinc content. Fonseca (1997) found no effect on Daphnia similis, while Ceriodaphnia silvestrii showed a chronic effect. In an evaluation of sediment quality at a sampling station in the Piracicaba River basin, Melleti (1997) identified a sign of toxicity in a fish species (Prochilodus scrofa), which was not observed in Ceriodaphnia silvestrii and Daphnia similis when exposed to the same sample by Fonseca (1997).

The results of our acute toxicity bioassays with Daphnia similis refute the theory that the quality of the water improves along the cascade of reservoirs, possibly because of the presence of pollutants. According to Weltens et al. (2000), many pollutants are retained in suspended solids present in water, which may decrease their toxicity. Metals in water are commonly analyzed by atomic absorption spectrometry, which leads to findings that sometimes contradict those of toxicity bioassays, which can express equivalent toxicity in much lower concentrations of metal due to the complexity of those elements (Conney, 1995). No significant correlation was found between the metals in the water samples and the acute and chronic toxicity test data.

Another important class of ecosystem pollutants is persistent organic pollutants (POPs), such as dioxins and organochloric pesticides, which were not evaluated in this study. In their analysis of water samples from 38 reservoirs in 7 hydrographic basins in the state of São Paulo (Paranapanema, Paraná, Iguape, Tietê, Paraíba, Pardo and Grande rivers), Cáceres et al. (1987) found BHC and DDT residues (organochloric pesticides) in all of them.

According to Larsson et al. (2000), eutrophic lakes contain a great phytoplanktonic biomass due to the excess of nutrients, causing POP retention and greater sedimentation of these pollutants, unlike oligotrophic lakes, where POP is more readily transferred to the food web. Thus, in the Tietê reservoirs, possible organic pollutants would not be totally available in the waters of the Tietê and Piracicaba rivers and in the first reservoir of the cascade (Barra Bonita), which are considered eutrophic, unlike the reservoirs downstream 
(mesotrophic and oligotrophic). The high values of total suspended matter found in the Tietê and Piracicaba river water and in the upper reservoirs of the cascade may have prevented the availability of certain metals and other pollutants from affecting Daphnia similis and, hence, from causing a toxic effect in these organisms.

The study reported here found that water quality in the middle and lower Tietê watershed is degraded. Large amounts of pollutants such as heavy metals, pesticides and barely degradable organic compounds can affect water quality in reservoirs. Toxicity bioassays are important in evaluating the degree of environmental toxicity. However, once toxicity is proven, the Toxicity Identification and Evaluation (TIE) approach must be incorporated into water resources monitoring because of its importance in identifying compounds responsible for toxicity (Paschoal, 2002). The TIE method is a tool serving to isolate and characterize the physicochemical nature of toxicants in complex samples based on knowledge of how factors such as $\mathrm{pH}$ and hardness modify toxicity (Rand et al., 1995).

Acknowledgments - The authors would like to thank the Higher Education Improvement Council (CAPES) for the scholarships granted, the PROBIO MMA/CNPq Project and the technicians of the Center for Water Resources and Applied Ecology (CRHEA), the São Carlos School of Engineering (USP), and the Federal University of São Carlos Department of Ecology and Evolutionary Biology (DEBE).

\section{REFERENCES}

ARMENGOL, J., 1977, Tipologia dos embalses españoles, p. 3 6. In: Seminario sobre medio ambiental y embalses. Anais, Tomo I, Montevideu.

ASSOCIAÇÃO BRASILEIRA DE NORMAS TÉCNICAS, 1968, MB 32 Análise Granulométrica de Solos Método Brasileiro, $7 \mathrm{p}$.

BARBOSA, F. A. R., PADISÁK, J., ESPÍNDOLA, E. G. L., BORICS, G. \& ROCHA, O., 1999, The Cascading Reservoir Continuum Concept (CRCC) and its application to the River Tietê - Basin, São Paulo State, Brazil, pp. 425-437, In: J.G TUNDISI \& M STRAŠKRABA (eds), Theoretical Reservoir Ecology and its Applications. Brazilian Academy of Sciences and Backhuys Publishers, Rio de Janeiro.

BARBOSA, R. M., 2000, Avaliação do impacto de lodo de estações de tratamento de água à biota aquática através de estudos ecotoxicológicos. Tese de Doutorado, Escola de Engenharia de São Carlos, Universidade de São Paulo, São Carlos, $200 \mathrm{p}$.

BURTON, G. A. JR. \& MACPHERSON, C., 1995, Sediment toxicity testing issues and methods. In: D. J. HOFFMAN,
G. A. RATTNER., G. A. JR. BURTON, JR CAIRNS (eds), Handbook of Ecotoxicology, Lewis Plublishers, Boca Raton Fl. New York.

CÁCERES, O., TUNDISI, J. G., \& CASTELlAN, O. A. M, 1987, Residues of organochloric pesticides in reservoirs in São Paulo States, Ciência e Cultura, 39: 259-264.

COMPANHIA DE TECNOLOGIA DE SANEAMENTO AMBIENTAL, CETESB, 1991a, Água e teste de toxicidade aguda com Daphnia similis Claus, 1876 (Cladocera, Crustacea). Norma Técnica, L5.018, São Paulo, 33 p.

COMPANHIA DE TECNOLOGIA DE SANEAMENTO AMBIENTAL, CETESB, 1991b, Água e teste de toxicidade crônica utilizando Ceriodaphnia dubia Richard, 1894 (Cladocera, Crustacea). Norma Técnica L5.022, São Paulo, $30 \mathrm{p}$.

CONSELHO NACIONAL DO MEIO AMBIENTE, 1986, Legislação ambiental brasileira. Resolução do Conselho Nacional do Meio Ambiente, CONAMA 20/1986. IBAMA, Brasília.

COONEY, J. D., 1995, Freshwater test, pp. 71-98. In: G. M. RAND (ed), Fundamentals of aquatic toxicology: effects, environmental fate, and risk assessment. Taylor \& Francis, Washington.

ESTEVES, F. A., FERREIRA, J. R., PESSENDA, L. C. R. \& MORTATTI, J., 1981, Análises preliminares sobre o teor e a distribuição de metais em sedimentos de represas do Estado de São Paulo, pp. 323-342. In: II Seminário Regional de Ecologia. São Carlos, Anais, UFSCar, São Carlos.

ESTEVES, F. A., 1988, Fundamentos da Limnologia. Interciências FINEP, Rio de Janeiro. 602 p.

FONSECA, A. L., 1997, Avaliação da qualidade da água na Bacia do Rio Piracicaba através de testes de toxicidade com invertebrados. Tese de Doutorado, Escola de Engenharia de São Carlos, Universidade de São Paulo, São Carlos, 211 p.

GOLTERMAN, H. L, CLYMO, R. S. \& OHNSTAD, R., 1978, Methods for physical and chemical analisys of freshwater, $2^{\circ}$ ed, Blackwell Science, IBP Handbook, London, 213 p.

GÜNTZEL, A. M., 2000, Variações espaço-temporais da comunidade zooplanctônica nos reservatórios do médio e baixo rio Tietê/Paraná. Tese de Doutorado, Universidade Federal de São Carlos, São Carlos, 445 p.

LARSSON,P.,ANDERSSON,A., BROMAN, D., NORDBÄCK, J. \& LUNDBERG, E., 2000, Persistent organic pollutants (POPs) in pelagic systems, Ambio, 29: 202-209.

MARGALEF, R, 1983, Limnologia, Omega. S.A, Barcelona, $1010 \mathrm{p}$.

MATSUMURA -TUNDISI, T., HINO, K. \& CLARO, S., 1981, Limnological studies at 23 reservoir in southern part of Brazil. Verh. Internat. Verein. Limn., 21: 1040-1047.

MELETTI, P. C., 1997, Avaliação da qualidade da água na bacia do rio Piracicaba através de testes de toxicidade aguda com peixes. Dissertação de Mestrado, Escola de Engenharia de São Carlos, Universidade de São Paulo, São Carlos, $148 \mathrm{p}$.

PASCHOAL, C. M. R. B., 2002, Avaliação ecotoxicológica de sedimentos em reservatórios da bacia do Rio Tietê, $S P$, com ênfase na aplicação e identificação da toxicidade. 
Tese de Doutorado, Escola de Engenharia de São Carlos, Universidade de São Paulo, São Carlos, 146 p.

PRATER, B. L. \& ANDERSON, M. A., 1977, A 96 hours bioassay of Duluth and Superior Harbor Basins (Minnesota) using Hexagenia limbata, Aselus communis, Daphnia magna, and Pimephales promelas as test organisms. Bull. Environm. Contam. Toxicol, 18: 159-169.

RAND, G. M, WELLS, P. G., \& McCARTY, L. S., 1995, Introduction to Aquatic Toxicology, pp. 3-66. In: G.M. RAND (ed), Fundamentals of aquatic toxicology: effects, environmental fate, and risk assessment, Taylor \& Francis, Washington,

ROCHA, O., ESPÍNDOLA, E. L. G., REIS, R. \& SEVERI, W., 2000, Aspectos estruturais e funcionais das cascatas de reservatórios do baixo rio São Francisco, Brasil, pp 40. In: Seminário Internacional. Represa do Lobo-30 anos de Pesquisa em Limnologia, Gerenciamento e Participação da Comunidade e Bases Científicas para o Gerenciamento da Eutrofização. Resumos. UFSCar-USP, São Carlos.

SANDES, M. A. L., 1990, Flutuações e fatores ecológicos, composição e biomassa do fitoplâncton em curto período de tempo no reservatório de Álvaro de Souza Lima (Bariri, S.P). São Carlos. Dissertação de Mestrado, Escola de Engenharia de São Carlos, Universidade de São Paulo, São Carlos, $111 \mathrm{p}$.

SÃO PAULO (ESTADO), 1982, Coordenadoria da Indústria e do Comércio. Diretrizes para a Política de Desenvolvimento e Desconcentração Industrial. Governo do Estado de São Paulo.133 p.

SEVERI, W., REIS, R., ROCHA, O. \& ESPÍNDOLA, E. L. G., 2000, Características limnológicas de reservatórios do submédio rio São Francisco. pp. 42, In: Seminário Internacional. Represa do Lobo-30 anos de Pesquisa em Limnologia, Gerenciamento e Participação da Comunidade e Bases Científicas para o Gerenciamento da Eutrofização. Resumos. UFSCar-USP, São Carlos.

STANDARD METHODS FOR THE EXAMINATION OF WATER AND WASTEWATER, 1995, For examination of water and wastwater. In: A. D. Easton et al (eds), $19^{\text {th }}$ ed. American Publish Health Association, Washington, 1269 p.

STRAS̆KRABA, M., 1994, Vltava cascade as teaching grounds for reservoir limnology. Wat.Sci.Tech., 30: 289-297.

TEIXEIRA, C., TUNDISI, J. G. \& KUTTNER, M. B., 1978, Plankton studies in a mangrove. II. The standing - stock and some ecological factors. Bol. Inst. Oceanogr., 24: 23-41.

TESSIER, A. \& CAMPBELL, P. G. C., 1987. Partitioning of trace metals in sediments: relationships with bioavailability. Ecological effects of in situ sediment contaminants, Hidrobiol, 149: 43-51.

THOMAZ, S. D., BINI, L. M \& ALBERTINI, S. M., 1997, Limnologia do reservatório de Segredo: padrões de variação espacial e temporal, pp. 19-37. In: A. A. AGOSTINHO \& L. C GOMES (eds), Reservatório de Segredo: bases ecológicas para o manejo. Eduem Maringá.

TUNDISI, J. G., 1999, Reservatórios como sistemas complexos: teoria, aplicações e perspectivas para usos múltiplos, pp. 19-38. In: R. HENRY (ed), Ecologia de Reservatórios, FUNDIBIO FAPESP, Botucatu.

TUNDISI,J.G.MATSUMURA-TUNDISI,T.CALIJURI, M. C. \& NOVO, E. M. L., 1991, Comparative limnology of five reservoirs in the middle Tietê River, São Paulo State. Verh. Internat. Verein. Limn., 24: 1489-1496.

WELTENS, R., GOOSSENS, R. \& VAN PUYMBROECK, S., 2000, Ecotoxicity of contaminated suspended solids for filter feeders (Daphnia magna). Arch.Environ.Contam. Toxicol., 39: 315-323.

WETZEL, R. G., 1993, Limnologia. Fundação Calouste Gulbenkian, Lisboa, 919 p. 